\title{
The biology of talc
}

\author{
GAVIN Y. HILDICK-SMITH \\ Clinical Assistant Professor of Paediatrics, College of Medicine and Dentistry \\ of New Jersey, Rutgers Medical School
}

\begin{abstract}
Hildick-Smith, G. Y. (1976). British Journal of Industrial Medicine, 33, 217-229. The biology of talc. Data are presented on the effects on health of talc dusts from exposure in industry and use of talc-containing health products. The mineralogy of talc and the composition of cosmetic and industrial grade talc dusts are described. Studies in animals are reviewed, and epidemiological data are considered in relation to exposures that occur during industrial and consumer uses of talc dusts. Hamsters exposed to $8 \mathrm{mg} / \mathrm{m}^{3}$ of respirable cosmetic grade talc dust for up to 150 minutes a day for 300 consecutive days showed no difference in incidence or nature of pathological lesions from those observed in a group of untreated animals. A retrospective study of the causes of death of 227 talc mine millers exposed to cosmetic grade talc at the threshold limit value for talc ( 20 million parts per cubic foot) for an average of 15.8 years showed that the causes of death were no different from those in a control cohort not exposed to talc dust. The available data indicate that talc dust exposure in the modern mining of cosmetic grade talc does not appear to be injurious to health. The significantly lower dust

exposure in the normal use of cosmetic grade talc dusts in talc-containing health and cosmetic products confirms that their use is not a hazard to health.
\end{abstract}

Increasing interest in the impact of environmental influences on health has in recent years focused attention on the significance of pollutants and prompted a reappraisal of environmental mineral dusts that have had extensive long-term use, but on which there is a paucity of correlated scientific data by which to evaluate them (Davies, 1964a; Gross, DeTreville, and Cralley, 1970; Lee, 1972; Schaefer, Mohnen, and Veirs, 1972; Editorials, British Medical Journal, 1973; Food and Cosmetics Toxicology, 1973; Lancet, 1973; New England Journal of Medicine, 1973; Selikoff, 1973).

The effects of talc dusts on the health of miners and industrial workers have been studied extensively and dust level standards that are considered safe have been established by official agencies (Hogue and Mallette, 1949; Schepers and Durkan, 1955a; Kleinfeld et al., 1964a, and b, 1967; Riley, 1965; Morgan, Ozolins, and Tabor, 1970; Murphy et al., 1971; Smith, 1971; Hatch, 1973; Kleinfeld, Messite, and Langer, 1973; Leroux, Davey, and Paillard, 1973;
American Conference of Government Industrial Hygienists, 1973; Wegman et al., 1974). The potential health hazard of dusts encountered by consumers who have no industrial exposure has become a subject of increasing interest (Henderson et al., 1971; Merliss, 1971; Nam and Gracey, 1972; Blejer and Arlon, 1973).

Asbestos dust has been shown to be a health hazard (Wright, 1969; Gross et al., 1970; Murphy et al., 1971; Smith, 1971; Stanton and Wrench, 1972; Smith, 1973; Stanton, 1974; Haley, 1975) and can cause cancer (Wagner, Sleggs, and Marchand, 1960; Selikoff, 1970, 1973) after exposure above a calculated threshold level of 125 million parts per cubic foot years (Enterline, DeCoufle, and Henderson, 1973). As some talc dusts contain asbestos, attention has been focused on the possibility that talc dust contaminated by asbestos may be harmful or talc dust itself may be hazardous (Blejer and Arlon, 1973; Pelfrène and Shubik, 1975).

Talc was first mined by the ancient Greeks and 
currently has wide use in a variety of products and industrial processes. Although talc dust has been used for many years, there is only limited modern scientific information available regarding its biological activity by which to assess accurately its safety when used in industry or by the consumer. The older information that is available is difficult to interpret, since the term talc is used to describe both the cosmetic grade of talc and also mineral powders of mixed composition that are used in industry and known as industrial grade talc (Smith, 1971). Accordingly, it seemed pertinent to review the available data on the biology of various talc dusts to determine whether the current guidelines for industrial exposure (American Conference of Government Industrial Hygienists, 1973) are adequate, and to assess whether exposure to the grade of talc in cosmetic products is a hazard to health under normal conditions of use.

\section{Mineralogy}

Talc as a pure chemical compound is defined as hydrous magnesium silicate, $\mathrm{Mg}_{3} \mathrm{Si}_{4} \mathrm{O}_{10}(\mathrm{OH})_{2}$ and consists of a brucite sheet containing magnesium ions sandwiched between two silica sheets which are held together by relatively weak forces. A variety of elements such as nickel and iron may be included in the talc particle lattice but are so bound within the particle that they are not free to exert any biological action (Gross and Harley, 1973). Talc can be tabular, granular, fibrous, or platy but it is usually crystalline, flexible, and soft. It is commonly whitish to light green but it can be yellowish to reddish, the reddish colour being associated with small amounts of iron bound within the talc particle (Deer, Howie, and Zussman, 1962; Chudzikowski, 1975). Talc is a member of the family of silicate minerals which have a similar atomic structure and occur widely in a large number of different varieties. These silicate minerals are derived from metamorphic alteration of mineral rocks which sometimes include the amphibole and serpentine groups of asbestos after their exposure to specific temperatures, pressures, and circulating liquid solutions. Talc may also be formed by the thermal metamorphism of silicon dolomites.

The purity and physical form of any sample of talc dust as well as the other minerals that are associated with it are therefore directly related to the source of the talc and to the minerals found in the ore body from which it is mined. Talc commonly contains chlorites and carbonates, the former being sheet silicate minerals containing magnesium, aluminium, and iron. The carbonate mineral components of talc are mainly magnesite, dolomite, and calcite. Quartz (free silica), iron oxides, sulphides, and various silicates can also be associated with talc.
As serpentine is one of the minerals from which talc has evolved, it can be associated with talc and is sometimes a contaminant of talc dust. Tremolite, a member of the amphibole group of asbestos, and chrysotile or antigorite of the serpentine group, are the commonest asbestos contaminants of industrial talc dust, although chrysotile has never been reported to be present in the high-grade talc used in health and cosmetic products (Pooley, F. D., personal communication, 1975).

As talc dusts are obtained from different sources, the amount and specific form of talc, as well as the amount and nature of mineral contaminants, will be different for each dust.

The wide range of mineral components and talc forms in talc dusts has made it possible to identify grades of talc dusts with specific physical properties which make them suitable for use in various industrial processes as well as in health care and cosmetic products. It is important therefore to realize that the effect on health of talc dusts will relate to the specific mineral composition of a talc dust, although it may be possible to relate health effects to identified grades of talc. For instance, talc used in health and cosmetic products is of high grade and is identified as cosmetic grade talc which contains more than $90 \%$ mineral talc, is free of detectable asbestos, and contaminated by only limited amounts of other minerals. The talc particles in cosmetic grade talc are the flat, plate-like variety which are selected for their lubricity. Cralley et al. (1968) reported an average of $19 \%$ incidence of fibres in 22 cosmetic talc samples studied, but detailed analysis of such talcs shows their fibre content to be of a lower order, as the reported high incidence of fibre in platy talcs relates to the fibrous appearance of a broken plate or a talc platelet seen on edge when examined under a microscope.

Industrial talc dusts which are used in a wide range of industrial processes or products are selected for their desired physical properties and therefore have a varied mineral composition. Industrial talcs may not actually contain talc or they may have a low talc mineral content. They may contain asbestos or significant concentrations of free silica as well as a wide variety of other mineral dusts.

The particle size of a sample of talc powder will vary in relation to the process used to make the powder with common cosmetic talcs having particles ranging between $0.3 \mu \mathrm{m}$ to $50 \mu \mathrm{m}$ in size with only a minor fraction (by weight) consisting of particles usually considered to be of respirable size.

The precise mineralogical identification of fibres or other mineral contaminants is essential for determining the exact composition of a talc dust and among the analytical methods used to establish the identity of particles are differential thermal analysis, $x$-ray diffraction, and microscopical examination (Rolle, Schelz, and Hamer, 1976). 


\section{Commercial uses}

Approximately 800000 tonnes of talc are used commercially in the United States of America each year. Because of the lubricious property and chemical inactivity of talc, it is used in the leather, rubber, paper, textile, and machine construction industries. It is also used as an additive for paints, in the roofing and ceramic tile industry, and as a carrier for insecticides and herbicides. Altogether 30000 tonnes of cosmetic grade talc are used in cosmetic and pharmaceutical products and as fillers, and in some foodstuffs (Wright, 1969).

\section{Cellular and tissue response to talc}

The development of pathological lesions in the lungs after inhalation of some mineral dusts has led to an interest in determining the amount required to produce pulmonary disease, the effect of dusts on cells and cell function, and the precise biological process by which disease is produced. One means of assessing the biological activity of dusts has been to study their effect on the viability and function of cells (Hayashi, 1971). In these studies, red cells, peritoneal and pulmonary macrophages, bacteria, and fibroblasts have been used (Stalder and Stoeber, 1965; Allison, Harington, and Birbeck, 1966; Parazzi, Secchi, and Pernis, 1968; Kleinfeld, 1970; Schnitzer and Pundsack, 1970; Beck, Holt, and Nasrallah, 1971; Bey and Harington, 1971; Schnitzer, Bunescu, and Baden, 1971; Rajan, Wagner, and Evans, 1972; Bowden, 1973; Harington, Ritchie, and King, 1973; Maroudas, O'Neill, and Stanton, 1973; Ackerman and Beebe, 1974).

Although the cellular effect of silica and asbestos dusts has been extensively studied (Allison et al., 1966; Parazzi et al., 1968; Beck et al., 1971; Harington et al., 1973; Rajan et al., 1972) little research has been conducted on the effect of talc on cells. Schnitzer and Pundsack (1970), using a red cell haemolysis test (Stalder and Stoeber, 1965), reported that marked haemolysis occurred with chrysotile, but that none of the amphibole asbestiform minerals (crocidolite, amosite, and anthophyllite) was substantially active. Minerals described as non-asbestiform fibrous materials, including fibrous talc (the fibrous component being predominantly tremolite) were rated as actively producing haemolysis, but miscellaneous materials studied, which included platy talc, were found to be inactive.

Di Luzio, N. (personal communication, 1975) reported that commercially available cosmetic grade talc dust did not alter the viability of pulmonary macrophages in rats or interfere with their uptake of colloid particles.

Kleinfeld (1970) studied the effect of quartz, cristobalite, and a commercial talc containing magnesium aluminium silicate, manganese dioxide, and $3.2 \%$ free silica on the cellular growth of primary embryonic lung explants grown in vitro and reported they produced an outgrowth of fibroblast cells, with relatively few epithelial cells. Chrysotile and anthophyllite asbestos fibres produced an outgrowth of epithelial cells that were invaded by sheets of cells resembling fibroblasts. Kleinfeld speculated that free silica and asbestos dusts accelerate the transformation of the macrophages to fibroblast cells with the production of collagen initiating the fibrotic process. In contrast, a pure crystalline talc produced a response similar to that of the control cultures, in which only epithelial outgrowth occurred.

Available information on the cellular effect of mineral dusts indicates that platy talc is inactive, unlike the fibrous dusts silica and crocidolite which have significant biological activity. The data suggest that platy talc itself produces minimal cell toxicity, but that when contaminated with significant amounts of either silica or cytotoxic minerals such as chrysotile, the tissue response within the body is related to the cellular response to the cytotoxic minerals rather than to the particles of talc.

\section{Pharmacogenetic studies}

As talc dust can come into contact with a variety of cell types when inhaled, its mutagenic potential was assessed using the host-mediated assay (Gabridge, Denunzio, and Legator, 1969), cytogenetic studies (Legator, 1969), and the dominant lethal assay (Epstein and Shafner, 1968; US Food and Drug Administration, 1974), using both in vitro and in vivo tests.

In the in vivo studies which were conducted in rats, the talc was given orally in doses of 30,300 , and 3000 $\mathrm{mg} / \mathrm{kg}$ and the results compared with an oral dose of $0.3 \mathrm{mg} / \mathrm{kg}$ of triethylene melamine.

In the in vitro studies talc dose levels of 2,20 , and $200 \mu \mathrm{g} / \mathrm{ml}$ were used and compared with $0.1 \mu \mathrm{g} / \mathrm{ml}$ of the positive control triethylene melamine. In the in vitro host-mediated assay the results were negative while in the in vivo studies there was no significant increase in the mutant or recombinant frequencies in the Salmonella and Saccharomyces species used.

The in vitro cytogenetic studies showed that talc produced no significant aberration in the anaphase chromosomes of human tissue culture cells. In the in vivo cytogenetic study no detectable significant aberration of the bone marrow metaphase chromosomes was seen in rats given talc.

In the dominant lethal study, male rats were fed the talc doses used in in vivo studies and mated with virgin female rats. The number and nature of fetuses from matings with rats treated with talc as well as the active and passive control were recorded. Talc did not alter the number and type of fetuses and could be considered non-mutagenic.

The data obtained from these sophisticated studies show that talc is not a mutagen and therefore is 
unlikely to produce cancer or induce congenital deformity in fetuses.

\section{Studies in animals}

Animal studies have been used extensively to simulate industrial conditions and to assess the histological response to test dusts (Schulz and Williams, 1942; Saxen and Tuovinen, 1947; Schepers and Durkan, 1955b; Luchtrath and Schmidt, 1959; Bluemel, Pizá, and Zischka-Konorsa, 1962; Cygielman and Robson, 1963; Grigor'ev, 1963; Rakowski, 1964; BethgeIwanska, 1971; Pott and Friedrichs, 1972; Stanton and Wrench, 1972; Wagner, Berry, and Timbrell, 1973; Stanton, 1974).

In most studies conducted with talc dust the precise mineral composition, particle size, and dose administered have not been defined and only recently have data on these variables been reported. Useful information can be obtained from experiments in animals in which talc was studied specifically or was used as a control in the study of other materials.

Grigor'ev (1963) compared the tissue reaction of the shaved skin of rabbits when spodumena (triphane $\mathrm{LiAl} / \mathrm{SiO}_{2}$ ) talc and silica were separately applied to the skin under patches daily for 90 days. The skin treated with spodumena showed marked histological changes while no abnormal changes were reported with talc or quartz. These data indicate that talc dust is not a primary irritant to the skin nor will it induce sensitization in animals, a finding which has been well confirmed in man.

Talc can produce local fibrosis when introduced into tissues (Saxen and Tuovinen, 1947); Cygielman and Robson (1963) showed that while $10 \mathrm{mg}$ of talc administered intramuscularly in rats every day for four days produced no local fibrosis, $50 \mathrm{mg}$ of talc similarly administered produced a local granuloma.

Bluemel et al. (1962) studied the histological response of talc powder and a starch surgical glove product when the two powders were administered intraperitoneally in rats. Approximately $400 \mathrm{mg}$ of the starch product and talc were introduced by laparotomy into the peritoneal cavity of two groups each comprising 30 rats; 10 rats were used as a control and were untreated except for a sham operation. Histological examination of the talctreated animals showed production of granuloma, and in the starch-treated animals loosely structured granulation tissue.

\section{Pulmonary studies in animals}

As inhaled talc dusts may produce pulmonary disease, animal inhalation studies have been conducted to assess the pulmonary response to various talc dusts (Schepers and Durkan, 1955b; Luchtrath and Schmidt, 1959; Bethge-Iwanska, 1971).

Schepers and Durkan (1955b) conducted studies in rabbits, rats, and guinea-pigs to assess the individual and collective histological effects of tremolite anthophylite, quartz, serpentine, and dolomite present in a commercial talc mined in upper New York State which had produced pneumoconiosis in some mine workers. In the study the dusts varying in particle size were administered intravenously or intratracheally to animals and the histological response of the lung tissue was assessed at various times after administration. The authors concluded from their extensive studies that talc was dominantly cytogenic while tremolite and anthophylite have cytogenic and fibrogenic properties, and that silica modifies the effects of these materials.

In 1959, Luchtrath and Schmidt conducted a study in rats designed to determine whether pulmonary fibrosis reported in some talc workers was due to the talc itself or its contamination by silica. Four separate samples of talc were used in which $50 \mathrm{mg}$ of four talc samples containing $0,2,3$, and $10 \%$ silica were suspended in water and administered intratracheally to rats which were subsequently followed-up for up to 660 days. It was shown that talc containing up to $3 \%$ silica produced minimal fibrosis of pulmonary tissue compared with marked fibrosis produced by talc containing $10 \%$ silica, and that pulmonary fibrosis reported in talc miners was related to exposure to talc containing significant amounts of silica and other fibrogenic minerals.

Bethge-Iwanska (1971) conducted a study in rats to assess their pulmonary tissue response after exposure to an aerosol of undefined cosmetic talc and a talc dust used industrially in rubber manufacturing and to check the effectiveness of the Polish regulations which allow an industrial talc dust level of $10 \mathrm{mg} / \mathrm{m}^{3}$. Cosmetic and industrial talc dusts were introduced separately six times a day into special chambers containing rats for six days a week up to nine months with animals killed for histological examination at 7 and 14 days, and at three, six, and nine months. Dust samples that were taken on introduction of the dust and one hour later showed an initial dust concentration of $383 \mathrm{mg} / \mathrm{m}^{3}$ and $23 \mathrm{mg} / \mathrm{m}^{3}$ after one hour for cosmetic talc. The data show that when the groups of rats were killed after nine months' talc exposure they had undergone a time-weighted exposure to $16848 \mathrm{mg}$ per hour $/ \mathrm{m}^{3}$, which is 2790 times the total dust exposure to which a baby is exposed in a two-year period.

Evaluation of the particle sizes of the dusts showed that $30 \%$ of the industrially-used talc was less than $10 \mu \mathrm{m}$ and $12 \%$ less than $5 \mu \mathrm{m}$. For the cosmetic talc $55 \%$ was less than $10 \mu \mathrm{m}$ and $19 \%$ less than $5 \mu \mathrm{m}$. Histological changes from the specific talc dusts were increased mucus secretion after 14 days with both dusts; fibrocellular nodules and emphysematous foci at six months, with thickened small artery walls were noted after six and nine months' exposure. At 14 days, alveolar macrophages were 
seen to contain talc dust, and at three and six months the macrophages filled the alveoli.

Bethge-Iwanska (1971) concluded that the two talcs studied prođuced similar non-specific inflammatory changes associated with fibrocellular reaction and some focal fibrosis without evidence of pneumoconiotic changes. It was noted that the degree of fibrosis seen with talc was significantly less than the confluent fibrosis seen in asbestosis or the fibrosis seen in silicosis.

Wehner et al. (1975) studied the effect of inhalation of a commercially available cosmetic talc powder in Syrian golden hamsters. The talc dust consisted of $97 \%$ mineral talc in platy form free of detectable asbestos and silica. Separate groups each containing 50 male and female hamsters were exposed to aerosols of the product for 3,30 , and 150 minutes a day for 30 and 300 consecutive days. The total aerosol dust concentration was adjusted to maintain an average of $8 \mathrm{mg} / \mathrm{m}^{3}$ of respirable talc dust in the animal chambers.

The cumulative exposure of the groups of hamsters to the respirable talc dust ranged from $12 \mathrm{mg}$ hours $/ \mathrm{m}^{3}$ to $6000 \mathrm{mg}$ hours $/ \mathrm{m}^{3}$, the latter corresponding to 1700 times the dose to which an infant is exposed during an equivalent period of time when dusted with a commercial talc-based baby powder (Sivertson, J. N., personal communication, 1976). There was no difference in viability or body weight between the treated hamsters and the untreated control animals. In addition, histological examination and the incidence of tumours of lungs, heart, stomach, liver, kidney, testes, and ovaries showed no difference between treated and control animals.

Wagner et al. (1975) evaluated the effect of a commercially available cosmetic grade talc dust administered orally, intrapleurally, and by inhalation in rats and compared the histological findings at natural death or when killed with data obtained by similar administration of a superfine chrysotile asbestos in another group of rats, and in an untreated group of rats. Altogether $20 \mathrm{mg}$ of talc or chrysotile suspended in physiological saline were injected into the right pleural space of two groups each containing 48 rats. Eighteen of the rats injected with chrysotile developed mesotheliomas while none was observed in the talctreated or untreated animals. In two groups each containing 32 rats $100 \mathrm{mg}$ of talc or chrysotile were fed daily for 101 days and the gastrointestinal tract of each animal was examined at natural death. One stomach leiomyosarcoma was found in the talc-fed rats and a similar tumour noted in the chrysotile-fed rats.

In an inhalation study (Wagner et al., 1975), groups of 48,24 , and 24 rats were exposed to a respirable concentration of $10.8 \mathrm{mg} / \mathrm{m}^{3}$ of talc or chrysotile for $7 \frac{1}{2}$ hours a day for five days a week for 3,6 , and 12 months respectively providing cumulative doses of 4140,8094 , and $16363 \mathrm{mg}$ hours $/ \mathrm{m}^{3}$. The highest doses of respirable talc dust to which the rats were exposed represent an exposure of 5400 times the maximum exposure to which a baby is exposed during an equal period of time when using talc as a dusting powder. The total dust exposure to the animals receiving the maximum duration of exposure is $\mathbf{2 7 0 0}$ times the maximum cumulative exposure for an infant during a two-year period. At natural death of the animals the histology of the respiratory tract was compared with that of rats similarly exposed to chrysotile dust as well as that of an untreated group of rats. The lungs of animals exposed to the higher talc and chrysotile doses had fibrosis rated as minimal to slight compared to the control rats' lungs which had a minimal amount of fibrosis. No lung tumours were observed in the control animals while one adenoma of the lung was noted in the talctreated animals and three adenomas, two adenomatoses, and one adenocarcinoma occurred in the chrysotile-treated animals.

These studies indicate that talc administered orally or intrapleurally does not cause cancer in rats, and malignant disease did not occur after its inhalation.

\section{Cancer studies in animals}

Appraisal of the carcinogenicity of talc is important as it has been suggested that prolonged exposure to talc, with or without asbestos contamination, may be associated with malignant changes (Henderson et al., 1971; Merliss, 1971; Blejer and Arlon, 1973; Pelfrène and Shubik, 1975), and that fibrous particles with specific dimensions may be carcinogenic (Stanton and Wrench, 1972; Maroudas et al., 1973). Pott and Friedrichs (1972) evaluated the role that fibrous particles of different chemical compositions and non-fibrous particles of similar chemical compositions played in the production of neoplastic tissue change. In their study, $25 \mathrm{mg}$ of test dusts dispersed in $2 \mathrm{ml}$ of sodium chloride solution were injected intraperitoneally in groups of 40 female rats on four occasions at weekly intervals with the rats being followed-up for $\mathbf{5 3 0}$ days. Fibrous dusts (chrysotile, nemalite, and glass fibre), which are similar in form but different in chemical composition, produced abdominal tumours while actinolite, biotite, pectolite, and talc which chemically resemble chrysotile but occur in grain or plate form did not produce abdominal tumours. In this study the authors reported that necropsies of animals treated with talc revealed detectable talc in the peritoneal cavity while chrysotile was not visible microscopically because of the severe fibrotic tissue response in chrysotile-treated animals.

In a study in hamsters (Smith et al., 1965; Smith, 1973) $25 \mathrm{mg}$ of test dusts dispersed in $0.5 \mathrm{ml}$ saline were administered intrapleurally to groups of 50 
animals which were allowed to live their normal life spans. Dusts of chrysotile and amosite were studied, as were a sample of talc composed of platy particles and a sample of talc used for industrial purposes which consisted of both fibrous and platy talc together with $57 \%$ tremolite and a small amount of antigorite. Eight and $\mathbf{1 0}$ of the animals in the groups of 50 given chrysotile and amosite developed pleural mesotheliomas while there were no tumours in the animals treated with the two separate talc dusts. Pleural granulomatous lesions which were small and focal were observed in the talc-treated animals as opposed to the large and more fibrous lesions that were observed in the pleura of the animals treated with chrysotile or amosite.

Gross et al. (1970) conducted a study in which chrysotile alone and chrysotile combined with nickel chloride were given intratracheally to rats and the results compared to a similarly given talc with a natural high nickel content and a talc with a naturally low nickel content. The animals were allowed to live out their lives. Necropsy failed to reveal any evidence of cancer in the animals treated with the two talc samples but cancerous lesions were produced in animals to which chrysotile was given.

In the animal studies so far conducted, talc has not been found to produce tumours when injected into the peritoneum or the pleural space, or when it was administered orally, intratracheally, or by inhalation and the animals were allowed to live out their life spans before necropsy. These animal data indicate that talc is not carcinogenic.

\section{Human exposure to talc}

The greatest human exposure to talc dust is when it is used industrially or while it is mined or milled. Exposure to cosmetic grade talc as used in cosmetic and health care products is infrequent and of short duration.

Published cases of talc pneumoconiosis, therefore, primarily concern subjects engaged in the mining or processing of talc and usually refer to data obtained before modern mining and environmental standards were implemented (Dreessen, 1933; Dreessen and Dalla Valle, 1935; Porro, Patton, and Hobbs, 1942; Greenburg, 1947; Millman, 1947; Hogue and Mallette, 1949; McLaughlin, 1950; Jaques and Benirschke, 1952; Alivisatos, Pontikakis, and Terzis, 1955; Kleinfeld, Messite, and Tabershawe, 1955; Schepers and Durkan, 1955a; Hunt, 1956; Nagelschmidt, 1960; DeVilliers, 1961; Coscia et al., 1963; Gaido, Capellaro, and Delmastro, 1963; Scansetti, Rasetti, and Ghemi, 1963; Dettori, Scansetti, and Gribaudo, 1964; Kleinfeld et al., 1964a, b, 1965, 1967, 1973; Graham and Gaensler, 1965; Weiss and Boettner, 1967; Fristedt, Mattsson, and Schutz, 1968; ElGhawabi, El-Samra, and Mehasseb, 1970; Kleinfeld,
1970; Selikoff, 1973; Wegman et al., 1974). In people not employed in the talc industry, only isolated cases of pulmonary changes have been reported where there was either accidental exposure or excessive usage of talc (Jacobziner and Raybin, 1963; Jenkins, 1963; Gouvea et al., 1966; Zientara and Moore, 1970; Atlee, 1972; Nam and Gracey, 1972).

The development of pulmonary disease associated with exposure to talc dust is directly related to the amount of dust in the environment, the duration of exposure, the nature of the talc and its contaminants, and the amount of respirable dust that enters the bronchi (Davies, 1964a and b; Muir, 1972; Léophonte et al., 1975).

The lung can clear the bronchi of dust by phagocytosis (Bowden, 1973), by ciliary action or via the lymphatics, thereby preventing pulmonary tissue damage when the dust load is not overwhelming or the dust is not inherently toxic. (Lancet, 1973). The clearing mechanism however can be affected by noxious agents such as cytotoxic drugs, cigarette smoke, or a dust load that is so excessive that the normal cellular functions are impaired (Haynes, 1931; Davies, 1964a ; Morgan et al., 1970; Lee, 1972; Schaefer et al., 1972; Lancet, 1973; New England Journal of Medicine, 1973; First, 1973; Ackerman and Beebe, 1974; Golde, Byers, and Finley, 1974).

Early reports of pneumoconiosis in talc miners were on men working in uncontrolled environments, often associated with excessive exposure to high concentrations of dust. The recognition that limitations were required for mining environments produced standards for various dusts. In the United States of America the legal limit for exposure to talc in industry is 20 million particles (non-fibrous) per cubic foot and 2 fibres per millilitre. The limit is modified for total dust including a percentage of quartz in accordance with the following formula,

$$
\frac{10 \mathrm{mg} / \mathrm{m}^{3}}{\% \text { quartz }+3} \text {, }
$$

and for respirable dust containing a percentage of quartz as follows:

$$
\frac{10 \mathrm{mg} / \mathrm{m}^{3}}{\% \text { quartz }+2}
$$

(Morrow and Cohen, 1959; Federal Register, 1969; Leroux et al., 1973; American Conference of Government Industrial Hygienists, 1973).

Although Thorel (1896) first reported pulmonary changes in talc miners, it is only recently that controlled epidemiological studies have been conducted to define precisely the factors that contribute to pulmonary changes in talc miners, and to determine the amount of talc dust to which they can be exposed without hazard to health.

Pulmonary morbidity studies in mine employees Kleinfeld et al. (1973) compared the health of 39 talc 
miners with a matched control group of 41 individuals who had not been exposed to talc. The study is of interest as the mined talc contained fibrous particles of tremolite and anthophyllite. Dust particle counts averaged 18 million particles per cubic foot (range 6 to 62), with the fibre averaging 43 fibres greater than $5 \mu \mathrm{m}$ long per $1 \mathrm{ml}$ (range 8 to $260 / \mathrm{ml}$ ). The miners had a mean exposure of $16 \cdot 2$ years (range 11 to 22 years). Although one of the miners had $x$-ray evidence of pneumoconiosis, clinical findings and chest radiographs in the mining group were similar to those of the non-mining group except that nine miners $(25 \%)$ had dyspnoea as opposed to three $(7 \%)$ of the non-mining group.

Data from a group of 35 miners previously studied in another talc mine, the nature of which was not indicated, were also compared with data from the 39 miners more recently surveyed. The 35 miners had been exposed to an average dust count of 23 million particles per cubic foot (range 2 to 70 ) with an average count of 159 fibres $(62$ to $371 / \mathrm{ml})$ over $5 \mu \mathrm{m} / \mathrm{ml}$ for a mean exposure of $17 \cdot 1$ years. Twelve $(31 \%)$ of the 35 miners had $x$-ray findings compatible with pneumoconiosis as opposed to one $(2 \%)$ $(P=<0.01)$ for the 39 miners exposed to less dust. In addition, $22(70 \%)$ of the 35 subjects had dyspnoea in the high dust exposure group as opposed to 10 (25\%) of the 39 low dust exposure $(\mathrm{P}=<0.01)$, while eight (22\%) had lung crepitations in the former group as opposed to two $(5 \%)$ in the latter group $(P=<0.05)$.

The data obtained from the 39 miners with low exposure indicate that talc miners with industrial exposure five days a week, eight hours a day for a mean of 16.2 years were not significantly affected by an environment in which there was an average of 18 million particles per cubic foot of talc containing an average of 43 fibres greater than $5 \mu \mathrm{m}$.

Fine et al. (1975) studied the effect of talc dust on the respiratory system of men working in the rubber industry. Eighty employees exposed to talc dust were studied and compared with a control group of 189 employees who worked in three separate adjacent plants and were not exposed to curing fumes, carbon black, or talc dust. Data on past health, occupation, smoking habits, and respiratory symptoms were collected by using a modified British Medical Research Council (MRC) questionnaire (Medical Research Council, 1960). Pulmonary function data were obtained using a Stead-Wells spirometer in which FEV 1 and flow values at 50,25 , and $12.5 \%$ of the forced vital capacity (FVC) were measured. The flow rates were size standardized by determining the flow rates of the largest FVC reading. Posteroanterior and lateral chest radiographs were taken, reviewed, and classified in accordance with the UICC-Cincinnati classification (UICC, 1970) for pneumoconiosis by a physician confirmed as a reader by the National Institute of Occupational Safety and Health.

The industrial grade talc to which the workers were exposed contained $42 \%$ mineral talc but it was considered to be uniform for the period during which the workers were exposed and contained less than $1 \%$ silica and 2 fibres per $\mathrm{ml}$. The dust count ranged from $0.51 \mathrm{mg} / \mathrm{m}^{3}$ to $3.55 \mathrm{mg} / \mathrm{m}^{3}$ with most of the workers being exposed to less than $1 \mathrm{mg} / \mathrm{m}^{3}$. It was considered that the maximum lifetime exposure of any worker was 2 million particles per cubic foot $x$ 30 years, or 60 million particles per cubic foot years, or approximately $1 \mathrm{mg} / \mathrm{m}^{3} \times 30$ years, or $30 \mathrm{mg} / \mathrm{m}^{3}$ years.

The pulmonary function of the 69 workers exposed to talc for up to nine years, and that of the 141 control workers showed no significant change as indicated by $\mathrm{FEV}_{1}, \mathrm{FVC}$, and ratio of $\mathrm{FEV}_{1} / \mathrm{FVC}$.

A review of pulmonary symptoms showed that there was no difference in the incidence of cough, phlegm, or wheezing in 22 non-smoking talc workers when compared with 51 non-smoking control subjects. However, there was a statistically significant increase in the incidence of these symptoms among the 58 talc workers who smoked as opposed to the 138 control subjects who smoked.

A study of lung radiographs of the talc workers revealed no changes definitely consistent with pneumoconiosis, although one of the exposed group had opacities rated greater than $1 / 1$ profusion in the UICC classification.

It was concluded from the data obtained on individuals exposed to the specific industrial talc used in processing rubber that in the light of the pulmonary morbidity noted the current threshold limit value for non-fibrous industrial talc should be lowered to avoid possible pulmonary disease from prolonged exposure to industrial talc dust.

Green and Sylwester (Hildick-Smith, 1975) initiated a pulmonary morbidity study in 70 employees working in a talc mine that produces cosmetic grade talc. Symptoms, pulmonary function data, and chest radiographs were compared in the employees and in a matched control group working in non-dusty industries. A Stead-Wells spirometer was used to obtain pulmonary function data and health data were gathered with the use of an MRC questionnaire. The employees had worked for an average of 4.6 years exposed to an average dust count of 7.6 million particles per cubic foot (34-96 years). Initial finding in the study showed that there was no difference in radiographic findings between the two groups studied or in the pulmonary function measurements of $F C_{1}, F E V_{1}$, or $F E V_{1} / F V C$ ratio when assessed as a percentage of predicted values using predictions derived from workers in nonmineral industries. The incidence of pulmonary symptoms was similar in the non-smokers in the two 
groups studied but in 62 miners who smoked the incidence of sputum production was statistically significantly higher than in the 247 matched nonsmoking control subjects.

The initial data obtained by Green and Sylwester (Green, G. M., 1974, personal communication) indicate that the environmental conditions so far encountered by the talc miners have not produced evidence of pulmonary disease but that smoking in talc miners produces pulmonary symptoms. The data obtained in the studies conducted by Fine et al.(1975) and Green and Sylwester indicate that under the environmental conditions described pulmonary function was not impaired in non-smoking workers, but pulmonary symptoms were associated with workers who smoked, the exact significance of which will be determined in future prospectivestudies(Bossé et al., 1975).

\section{Causes of death of talc mine employees}

Rubino et al. (1976) conducted a retrospective study of talc mine employees to determine whether the causes of death were different compared with a control population of agricultural workers not involved in dusty industries. Record was made of the cause of death of employees who had worked for more than one year between 1921 and 1950 in a talc mine producing cosmetic grade talc. Data were obtained on the cause of death of 704 miners and 227 millers who had worked for an average of 14.9 to 15.8 years respectively.

The millers were exposed to cosmetic grade talc containing no detectable asbestos but $0.5 \%$ silica at an average concentration of 20 million particles per cubic foot of talc dust, and the miners were exposed to 600 million particles of talc dust containing 5\% silica, from 1920 to 1950 . Respiratory deaths in the talc miners were significantly higher than in the controls, although the incidence of pulmonary cancer, all cancers and cardiovascular disease was statistically significantly lower for the miners than the control group. Millers exposed to commercially available cosmetic grade talc had a similar incidence of deaths from respiratory disease, lung cancer and all cancers, but a statistically lower incidence of cardiovascular deaths.

Rubino's data indicate that prolonged exposure to cosmetic grade talc at the current threshold limit value for talc ( 20 million particles per cubic foot) did not increase deaths from pulmonary cancer or pulmonary disease compared with a control group.

\section{Cancer}

Exposure to some mineral dusts in appropriate amounts can cause pneumoconiosis and in some instances can be associated with the development of cancer (Henderson et al., 1971; Murphy et al., 1971;
British Medical Journal, 1973; Wagner et al., 1973). There is a possibility that talc alone or talc contaminated with asbestos may be associated with cancer formation (Merliss, 1971; Blejer and Arlon, 1973), although cancer has not so far been reported from its use therapeutically in the pleural cavity (Honma et al., 1963) or accidental introduction into the abdominal cavity from ruptured surgeons' gloves.

Merliss (1971) suggested that the high incidence of stomach cancer in the Japanese was related to the presence of chrysotile in the talc with which rice in California is dusted before being shipped to Japan. Smith (1973), however, failed to induce cancer in animals by feeding them $1 \%$ chrysotile in their diets during their lifetimes. Henderson et al. (1971) reported finding particles they believed were talc in cancerous and normal ovarian, cervical, and endometrial tissue. In the study, Henderson used a replica technique in which particles were identified by microscopical examination but their mineral composition was not confirmed by analytical procedures.

Kleinfeld et al. (1973) analysed 91 death certificates in a talc mining population of 220 in order to determine not only the cause of death, but whether any specific illness occurred in the miners as opposed to the general population. The talc miners were drawn from a mining population in New York State and mined talc admixed with serpentine and tremolite as well as $5 \%$ silica (Weiss and Boettner, 1967). The average age at death of the miners was 60.4 years (range 38-84 years) as opposed to the 54.4 years' life expectancy of comparable white men in the USA.

The mean duration of exposure was 24.7 years (15-27 years), with dust counts ranging from 2 to 2800 million particles before 1945 and 0 to 360 million particles per cubic foot since 1946, depending on the location within the mine. The elapsed time from exposure to death from pneumoconiosis or its complications averaged 25.9 years. The deaths from carcinoma of the lung and pleura showed an overall mortality that was four times the expected rate for the population with the increase occurring in the 60 to 70 -year age group rather than in the 40 to 50 -year age group.

In 1973, Kleinfeld reviewed recent data on the cause of death of talc miners on whom he had previously published papers (Kleinfeld, 1970; Kleinfeld et al., 1967, 1973). He reported that during the years 1945-49 the mortality from cancer was four times the expected incidence, but that this incidence dropped and approached the expected mortality in the years 1960-64 and 1965-69. By May 1973, there was no difference in the expected and observed mortality from malignancy of lungs, pleura, peritoneum, or gastrointestinal tract.

The difference between the observed and expected mortality for cancer was statistically significant during $1950-54$ but not significant in $1960-64$ or 
1965-69. Kleinfeld concluded that the reduction in cancer mortality in the mines was directly related to improved environmental control which, when implemented in 1945 resulted in appreciable reduction in dust counts, although the fibre counts still exceeded the permitted threshold ( 2 fibres per $\mathrm{ml}$ ).

Rubino et al. (1976) showed that the overall incidence of pulmonary and all cancers reported in talc miners was statistically significantly lower than that observed in the control population, while the incidence of cancers for talc millers and their control groups was similar (Kerr and de Mesquita, 1975). The available data from animal and epidemiological studies show that talc dust is not carcinogenic.

\section{Cosmetic use of talc dust}

Cosmetic talc is used as a face powder and body powder by both adults and children to lubricate the skin and prevent chafing and discomfort caused by moisture and heat. It has been used as a cosmetic throughout the world for many centuries and there is no evidence that its normal use poses a hazard to health. However, in view of increasing interest in identifying hazardous dust pollutants in the environment, it was considered important to review reports on experience with cosmetic talc.

Although talc is used as a body powder by people of all ages, it is widely used for babies after bathing or nappy changing. The normal use of cosmetic talc in infants has not been reported to be harmful (Food and Cosmetics Toxicology, 1973) although the accidental aspiration of excessive amounts in infants has been reported to cause serious but reversible acute respiratory disease in some instances and death in isolated cases (Cless and Anger, 1954; Molnar, Nathenson, and Edberg, 1962; Jacobziner and Raybin, 1963; Jenkins, 1963; Hughes and Kalmer, 1966; Tortorolo and Romano, 1966; Lund and Feldt-Rasmussen, 1969; Paoli and Brandigi, 1970; Neimann et al., 1971).

A review of the literature since 1954 reveals 27 reported cases of accidental aspiration of excessive amounts of talc by infants and children aged between six months and three years of whom six died (Cless and Anger, 1954; Molnar et al., 1962; Jacobziner and Raybin, 1963; Jenkins, 1963; Gouvea et al., 1966; Hughes and Kalmer, 1966; Tortorolo and Romano, 1966; Lund and Feldt-Rasmussen, 1969; Paoli and Brandigi, 1970; Neimann et al., 1971). It is noteworthy that when corticosteroid administration was added to the usual supportive treatment, possibility of recovery was increased (Hughes and Kalmer, 1966; Lund and Feldt-Rasmussen, 1969).

Minimal data are available on the frequency with which talc dusting powders are applied to the body, let alone the amount of dust to which the individual is exposed. In an attempt to define the amount of talc to which infants are exposed during normal use of talc dust, a study was conducted (Eden, A., personal communication, 1972) in which the frequency of use in various sites as well as the duration of usage was determined. Information collected from 76 mothers normally using talc in the care of their babies, showed that the site and method of application of talcum powders varied widely. In $62 \%$ of applications only the nappy area was dusted, while the whole body, except the head, was dusted in $20 \%$ of the applications, with other body sites being dusted in the remaining $18 \%$. Mothers applied the talc by either dusting the skin directly or placing talc in the hand before application. Babies were powdered from one to nine times a day with a median frequency of dusting the nappy area five times each day, with the duration of powdering the nappy area being 3 to 25 seconds with a median time of 10 seconds.

In order to determine the amount of talc to which an infant and mother are exposed, a simulated study was conducted (Pooley, F. D., personal communication, 1972). As dusting of infants is of short duration, in order to attain a satisfactory sample the contents of a container of a commercially available product were either continually or intermittently dusted into a shallow tray from a height of 7 to $13 \mathrm{~cm}$ (3 to 5 inches). Air inlets of a gravimetric dust sampler were placed in the appropriate site for the infant's nose and $40 \mathrm{~cm}$ (16 inches) above the tray at the estimated nose site of the mother. The dust concentration for a simulated mother and infant were similar in the study conducted. Analysis of the data (Sivertson, J. N., personal communication, 1976) indicates that during a 10-second dusting period the total median dust concentration is 0.243 million particles per cubic foot. The median concentration then decreases to an average of 0.124 million particles per cubic foot during the 65 further seconds required for the dust to settle.

Therefore, a median exposure per application can be estimated at 0.1752 million particles percubicfootminutes by summing the 10 -second $(0.17$ minutes) application of 0.0413 million particles per cubic footminutes $(0.243 \times 0.17)$ with the 65 second $(1.08$ minutes) exposure of 0.1339 million particles per cubic foot-minutes $(0.124 \times 1.08)$. A median weekly exposure for five times a day, seven days a week would be $0 \cdot 102$ million particles per cubic foot-hours.

A further study to determine the respirable dust to which an infant is exposed during talc dusting showed that the average respirable dust concentration was $0 \cdot 10 \mathrm{mg}$ per $\mathrm{min} / \mathrm{m}^{3}$ when dust samples were obtained in actual use of talc by mothers (Sivertson, J. N., personal communication, 1976).

The threshold limit value for talc dust in the USA is 20 million particles per cubic foot exposure for an eight-hour work day giving a 40-hour exposure a week, which gives an exposure level of 800 million 
particles per cubic foot-hours per week to talc dust. An infant dusted on an average of five times a day for seven days a week is exposed to an estimated median weekly exposure of 0.102 million particles per cubic foot-hours, which is 7840 times less than that of a miner working for eight hours a day for five days a week in a dust environment of 20 million particles per cubic foot.

Pulmonary fibrosis was seen in an adult as a result of bizarre and excessive use of talc (Nam and Gracey, 1972). The patient died from causes not associated with the fibrosis which was discovered coincidentally at necropsy. The patient was reported to have used talc excessively for 20 years and for four years had applied it liberally three times a day and dusted his sheets with it nightly to an extent that his wife refused to sleep in the same bed. This excessive use apparently did not clinically impair the patient's health.

Moskowitz (1970) reported on a female patient who developed radiographic reticular densities and hazy nodules in both lungs after working for six years as an inspector of aerosol talc sprays. The patient worked one week out of every six by spraying each can briefly into the air at a rate of 25-50 sprays an hour, with no protection against dust inhalation. The patient improved symptomatically after treatment with corticosteroids and subsequent radiographs showed remarkable clearing of both lung fields. Her vital capacity also increased after treatment from 1150 to 1550 in three months. The response of this patient suggested to Moskowitz that if the diagnosis of talc pneumoconiosis is made early, the process can be arrested and reversed.

Data are available concerning the duration and frequency of use of talc dusts used normally for cosmetic purposes by adults. Some indication of the extent of exposure of a consumer to cosmetic talc dust can be obtained when a 1-minute a day exposure to cosmetic talc dust is compared with the 480minute exposure to talc dust that is encountered by a miner in a single day. A consumer using a cosmetic talc dust for 10 seconds and allowing 65 seconds for settling would be exposed to 0.102 million particles per cubic foot-hours of talc dust a week as opposed to an eight-hour exposure a day of a miner working at the threshold limit value level of 20 million particles per cubic foot of talc dust which provides an exposure of 890 million parts per cubic foot hours a week.

On the basis of these calculations the million particles per cubic foot-hours of talc dust exposure of a miner each week is approximately 7800 times that of consumer exposure each week.

\section{Conclusion}

The increased interest in the effect of environmental dusts on consumers and industrial workers has prompted a review of available data to assess the hazard to health that exists under current conditions of exposure to talc dusts.

Prolonged exposure to cosmetic grade talc at the threshold limit value for talc in industrial environments has not been associated with the development of pneumoconiosis or cancer.

Any health hazard that may exist is confined to the industrial use of industrial talcs rather than industrial exposure to cosmetic grade talcs.

The concern that has been expressed about the possible health hazard from consumer exposure to cosmetic talc is unwarranted as the consumer exposure is greatly below the time-weighted levels considered as a safe exposure to cosmetic grade talc in an industrial environment.

\section{References}

Ackerman, N. F. and Beebe, J. R. (1974). Release of lysosomal enzymes by alveolar mononuclear cells. Nature, 247, 475-477.

Alivisatos, G. P., Pontikakis, A. E., and Terzis, B. (1955). Talcosis of unusually rapid development. British Journal of Industrial Medicine, 12, 43-49.

Allison, A. C., Harington, J. S., and Birbeck, M. (1966). An examination of the cytotoxic effects of silica on macrophages. Journal of Experimental Medicine, 124, 141-154.

American Conference of Government Industrial Hygienists (1973). Threshold Limit Values for Chemical Substances in Workroom Air, Cincinnati, Ohio, 1973.

Atlee, W. E. (1972). Talc and cornstarch emboli in eyes of drug abusers. Journal of the American Medical Association, 219, 49-51.

Beck, E. G., Holt, P. F., and Nasrallah, E. T. (1971). Effects of chrysotile and acid-treated chrysotile on macrophage cultures. British Journal of Industrial Medicine, 28, 179-185.

Bethge-Iwanska, J. (1971). Pathomorphological changes in the respiratory system in experimental talcosis. Medycyna Pracy, 22, 45-57.

Bey, E. and Harington, J. S. (1971). Cytotoxic effects of some mineral dusts on Syrian hamster peritoneal macrophages. Journal of Experimental Medicine, 133, 1149-1169.

Blejer, H. P. and Arlon, R. (1973). Talc: A possible occupational and environmental carcinogen. Journal of Occupational Medicine, 15, 92-97.

Bluemel, G., Pizá, F., and Zischka-Konorsa, W. (1962). Animal experiments on tissue reaction to the intraperitoneal use of starch and talcum powders. Wiener Klinische Wochenschrift, 74, 12-13.

Bossé, R., Costa, P., Cohen, M., and Podolsky, S. (1975). Age, smoking inhalation and pulmonary function. Archives of Environmental Health, 30, 495.

Bowden, D. H. (1973). The alveolar macrophage and its role in toxicology. Critical Reviews in Toxicology, 2, 95-124.

British Medical Journal (1973). Editorial. Asbestos hazard. British Medical Journal, 4, 312-313. 
Chudzikowski, R. J. (1975). Spotlight on talc. Soap, Perfumery and Cosmetics, 48, 56.

Cless, D. and Anger, R. (1954). Asphyxia due to inhalation of children's toilet powder. Kinderaerztliche Praxis, 22, 506-508.

Coscia, G. C., Perrelli, G., Linari, F., and Martino, P. (1963). Clinical, radiological, electrocardiographic, and spirographic findings in workers in the talc extraction industry. Archivio per le Scienze Mediche, 116, 329-335.

Cralley, L. J., Key, M. M., Groth, D. H., Lainhart, W. S., and Ligo, R. M. (1968). Fibrous and mineral content of cosmetic talc products. American Industrial Hygiene Association Journal, 29, 350-354.

Cygielman, S. and Robson, J. M. (1963). The effect of irritant substances on the deposition of granulation tissue in the cotton pellet test. Journal of Pharmaceutical Pharmacology, 15, 794-797.

Davies, C. N. (1964a). A comparison between inhaled dust and the dust recovered from human lungs. Health Physics, 10, 1029-1034.

- (1964b). Deposition and retention of dust in the human respiratory tract. Annals of Occupational Hygiene, 7, 169-183.

Deer, W. A., Howie, R. A., and Zussman, J. (1962). Rock Forming Minerals, ch. 3, pp. 121-123. Longman, London.

Dettori, G., Scansetti, G., and Gribaudo, C. (1964). Observations on air pollution in the talc industry. Medicina del Lavoro, 55, 453-455.

DeVilliers, A. J. (1961). Pneumoconiosis-a review. Part I. The biological significance of dusts. Occupational Health Review, 13, 3-14, and 18.

Dreessen, W. C. (1933). Effects of certain silicate dusts on the lungs. Journal of Industrial Hygiene, 15, 66-78.

— and Dalla Valle, J. M. (1935). The effects of exposure to dust in two Georgia talc mills and mines. Public Health Reports, 50, 131-143.

El-Ghawabi, S. H., El-Samra, G. H., and Mehasseb, H. (1970). Talc pneumoconiosis. Journal of the Egyptian Medical Association, 53, 330-340.

Enterline, P., DeCoufle, P., and Henderson, V. (1973). Respiratory cancer in relation to occupational exposure among retired asbestos workers. British Journal of Industrial Medicine, 30, 162-166.

Epstein, S. S. and Shafner, H. (1968). Chemical mutagens in the human environment. Nature, 219, 385-387.

Federal Register (1969). Title 41-Public Contracts and Property Management Chapter 50 Public Contracts, Dept. Labour Part 50-201-General Regulations Part 50-204 - Safety \& Health Standards Subpart DGases, Vapours, Fumes, Dusts, and Mists. Federal Register, 34, 7953.

Fine, L. J., Peters, J. M., Burgess, W. A., and Di Bernardinis, L. J. (1975). Studies of respiratory morbidity in rubber workers. In Proceedings of a Meeting of the American Occupational Medical Association, San Francisco, April.

First, M. W. (1973). Aerosols in nature. Archives of Internal Medicine, 131, 24-32.

Food and Cosmetics Toxicology (1973). Editorial. Living in a cloud of talc! Food and Cosmetics Toxicology, 11, 345-346.

Fristedt, B., Mattsson, S. B., and Schutz, A. (1968).
Talcosis. Nordisk Hygienisk Tidskrift, 49, 66-71.

Gabridge, M. G., Denunzio, A. L., and Legator, M. S. (1969). Microbial mutagenicity of streptozotocin in animal-mediated assays. Nature, 221, 68-70.

Gaido, P. C., Capellaro, F., and Delmastro, P. (1963). Various aspects of pneumoconiosis damage in talc millers. Minerva Medica, 34, 3605-3607.

Golde, D. W., Byers, L. A., and Finley, T. N. (1974). Proliferative capacity of human alveolar macrophage. Nature, 247, 373-375.

Gouvea, F. P., Gonsalves, P. E., Lebrun, E., and Ferraz de Faria, M. (1966). Acute aspiration of talc and other dusts: Bronchial lavage therapy. Revista do Hospital das Clinicas, Universidade de São Paulo, 21, 49-55.

Graham, W. G. B. and Gaensler, E. A. (1965). Talcosilicosis in a rubber worker. Medicina Thoracalis, 22, 590-604.

Greenburg, L. (1947). The dust hazard in tremolite talc mining. Yale Journal of Biological Medicine, 19, 481-501.

Grigor'ev, Z. E. (1963). Irritant action of spodumen concentrate dust on the integument of experimental rabbits. Vestnik Dermatologii $i$ Venerologii, 8, 13-15.

Gross, P. DeTreville, R. T. P., and Cralley, L. J. (1970). Studies on the carcinogenic effects of asbestos dust. In Pneumoconiosis: Proceedings of an International Conference, Johannesburg, 1969, edited by H. A. Shapiro, pp. 220-224. Oxford University Press, London.

- and Harley, R. A. (1973). Asbestos-Induced intrathoracic tissue reactions. Archives of Pathology, 96, 245.

Haley, T. J. (1975). Asbestosis: a reassessment of the overall problem. Journal of Pharmaceutical Sciences, 64, 1435-1449.

Harington, J. S., Ritchie, M., and King, P. C. (1973). The in-vitro effects of silica-treated hamster macrophages on collagen production by hamster fibroblasts. Journal of Pathology, 109, 21-37.

Hatch, T. F. (1973). Criteria for hazardous exposure limits. Archives of Environmental Health, 27, 231-235.

Hayashi, H. (1971). Interaction between minerals and the living body with reference to pneumoconiosis. Journal of the Geological Society of Japan, 77, 547-562.

Haynes, F. (1931). Experimental dust inhalation in guinea pigs. Journal of Hygiene, 31, 96-123.

Henderson, W. J., Joslin, C. A. F., Turnbull, A. C., and Griffiths, K. (1971). Talc and carcinoma of the ovary and cervix. Journal of Obstetrics and Gynaecology of the British Commonwealth, 78, 266-272.

Hildick-Smith, G. (1975). Talc. Review of epidemiological studies. In Proceedings of the 4th International Symposium on Inhaled Particles and Vapours, Edinburgh, September. (To be published.)

Hogue, W. L. and Mallette, F. S. (1949). A study of workers exposed to talc and other dusting compounds in the rubber industry. Journal of Industrial Hygiene and Toxicology, 31, 359-364.

Honma, N., Hiratsuka, N., Kozawa, E., Watanabe, A., Seijo, T., and Shimizu, M. (1963). Clinical aspects of spontaneous pneumothorax. Origin and therapeutic results in 70 cases. Journal of Therapy (Tokyo), 45, 2169-2174. 
Hughes, W. T. and Kalmer, T. (1966). Massive talc aspiration: Successful treatment with dexamethasone. American Journal of Diseases of Children, 111, 653-654.

Hunt, A. C. (1956). Massive pulmonary fibrosis from the inhalation of talc. Thorax, 11, 287-294.

Jacobziner, H. and Raybin, H. W. (1963). Accidental chemical poisonings: camphorated oil, talcum powder, and lead poisonings. New York State Journal of Medicine, 63, 3575-3577.

Jaques, W. E. and Benirschke, K. (1952). Pulmonary talcosis with involvement of the stomach and the heart. Archives of Industrial Hygiene and Occupational Medicine, 5, 451-463.

Jenkins, M. Q. (1963). Dusting powder inhalation. Journal of the South Carolina Medical Association, 59, 62.

Kerr, I. B. and de Mesquita, R. P. (1975). Growth inhibition of sarcoma 180 induced by silica and talc. Archiv für Geschwulstforschung, 45, 255.

Kleinfeld, M. J. (1970). Industrial pulmonary disease; clinical and experimental observations. Transactions of the New York Academy of Sciences, 32, 107-126.

- (1973). In Proceedings of a Symposium on Talc at the Bureau of Mines, Department of the Interior, Washington, D.C., 8 May.

—, Messite, J., Kooyman, O., and Shapiro, J. (1964a). Pulmonary ventilatory function in talcosis of lung. Diseases of the Chest, 46, 592-598.

,$--\ldots$, and Zaki, M. H. (1967). Mortality among talc miners and millers in New York State. Archives of Environmental Health, 14, 663-667.

,-- , and Langer, A. M. (1973). A study of workers exposed to asbestiform minerals in commercial talc manufacture. Environmental Research, 6, 132-143.

,-- , Shapiro, J., Kooyman, O., and Swencicki, R. (1964b). Lung function in talc workers. A comparative physiologic study of workers exposed to fibrous and granular talc dusts. Archives of Environmental Health, 9, 559-566.

,,--- , Swencicki, R., and Sarfaty, J. (1965). Lung function changes in talc pneumoconiosis. Journal of Occupational Medicine, 7, 12-17.

,-- , and Tabershaw, I. R. (1955). Talc pneumoconiosis. Archives of Industrial Health, 12, 66-72.

Lancet (1973). Editorial. Small particles in small airways. Lancet, 2, 948-949.

Lee, R. E. (1972). The size of suspended particulate matter in air. Science, 178, 567-575.

Legator, M. D. (1969). Cytogenetic studies in rats of cyclohexylamine, a metabolite of cyclamate. Science, $165,1139$.

Léophonte, P., Fabre, J., Pous, J., Albarède, J. L., and Delaude, A. (1975). Talc pneumoconiosis. Revue française des Maladies Respiratoires, 3, 363-384.

Leroux, J., Davey, A. B. C., and Paillard, A. (1973). Proposed standard methodology for the evaluation of silicosis hazards. American Industrial Hygiene Association Journal, 34, 409-417.

Luchtrath, H. and Schmidt, K. G. (1959). Talc and steatite, their relations with asbestos and their effect in intratracheal animal experiments on rats. Beiträge zur Silikose-Forschung, 61, 1-60.

Lund, J. S. and Feldt-Rasmussen, M. (1969). Accidental aspiration of talc; report of a case in a two-year old child. Acta Paediatrica Scandinavica, 58, 295-296.

Maroudas, N. G., O'Neill, C. H., and Stanton, M. F. (1973). Fibroblast anchorage in carcinogenesis by fibres. Lancet, 1, 807-809.

McLaughlin, A. I. G. (1950). Talc pneumoconiosis. Archives Belges de Médecine Sociale, Hygiene, Médecine du Travail et Médecine Legale, 8, 451-460.

Medical Research Council (1960). Standardised questionaries on respiratory symptoms. British Medical Journal, 2, 1665.

Merliss, R. R. (1971). Talc-treated rice and Japanese stomach cancer. Science, 173, 1141-1142.

Millman, N. (1947). Pneumoconiosis due to talc in the cosmetic industry. Occupational Medicine, 4, 391-394.

Molnar, J. J., Nathenson, G., and Edberg, S. (1962). Fatal aspiration of talcum powder by a child. New England Journal of Medicine, 266, 36-37.

Morgan, G. B., Ozolins, G., and Tabor, E. C. (1970). Air pollution surveillance systems. Science, 170, 289-296.

Morrow, C. S. and Cohen, A. C. (1959). The pneumoconioses. Medical Clinics of North America, 43, 171-190.

Moskowitz, R. L. (1970). Talc pneumoconiosis: A treated case. Chest, 58, 37-41.

Muir, D. C. F. (1972). Deposition and clearance of inhaled particles. Clinical Aspects of Inhaled Particles, edited by D. C. F. Muir, pp. 1-20. Davis, Philadelphia.

Murphy, R. L. H., Ferris, B. G., Burgess, W. A., Worcester, J., and Gaensler, E. A. (1971). Effects of low concentrations of asbestos. New England Journal of Medicine, 285, 1271-1278.

Nagelschmidt, G. (1960). The relation between lung dust and lung pathology in pneumoconiosis. British Journal of Industrial Medicine, 17, 247-259.

Nam, K. and Gracey, D. R. (1972). Pulmonary talcosis from cosmetic talcum powder. Journal of the American Medical Association, 221, 492-493.

Neimann, N., Vidailhet, M., Kiffer, B., Crance, J. P., Grun, G., and Andre, J. L. (1971). Accidental inhalation of talc in the newborn on two observations. Pédiatrie, 26, 81-84.

New England Journal of Medicine (1973). Editorial. Cleaner air. New England Journal of Medicine, 288, 909-910.

Paoli, F. and Brandigi, L. (1970). Five cases of inhalation of talc. Minerva Pediatrica, 22, 1772-1774.

Parazzi, E., Secchi, G. C., and Pernis, B. (1968). Studies on the cytotoxic action of silica dusts on macrophages in vitro. Archives of Environmental Health, 17, 851-859.

Pelfrène, A. and Shubik, P. (1975). Is talc a carcinogen. Review of present data. Presse Médicale, 4, 801-803.

Porro, F. W., Patton, J. R., and Hobbs, A. A., Jr. (1942). Pneumoconiosis in the talc industry. American Journal of Roentgenology, Radium Therapy and Nuclear Medicine, 47, 507-524.

Pott, F. and Friedrichs, K. H. (1972). Tumours in rats following I.P. injection of fibreform dusts. Naturwissenschaften, 59, 318.

Rajan, K. T., Wagner, J. C., and Evans, P. H. (1972). The response of human pleura in organ culture to asbestos. Nature, 238, 346-347.

Rakowski, W. (1964). Tissue reactions in guinea pig lungs during experimental talcum pneumoconiosis. Gruzlica 
i Choroby Pluc, 32, 671-67.6

Riley, E. C. (1965). Dust (Hygiene). In Kirk-Othmer. Encyclopedia of Chemical Technology, pp. 453-462. Interscience, New York.

Rolle, F. R., Schelz, J. P., and Hamer, D. (1976). The characterization of talc and associated minerals. American Industrial Hygiene Association Journal, in press.

Rubino, G., Scansetti, G., Piolatto, G., and Romano, C. (1976). Mortality studies of talc miners and millers. Journal of Occupational Medicine, 18, 186-193.

Saxen, A. and Tuovinen, P. I. (1947). Experimental and clinical observations on granulomas caused by talc and some other substances. Acta Chirurgica Scandinavica, 96, 131-151.

Scansetti, G., Rasetti, L., and Ghemi, F. (1963). Clinical and radiological evolution of pneumoconiosis in the talc extracting industry. Medicina del Lavoro, 54, 746-749.

Schaefer, V. J., Mohnen, V. A., and Veirs, V. R. (1972). Air quality of American homes. Science, 175, 173-175.

Schepers, G. W. and Durkan, T. M. (1955a). The effects of inhaled talc-mining dust on the human lung. Archives of Industrial Health, 12, 182-197.

— and (1955b). An experimental study of the effects of talc dust on animal tissue. Archives of Industrial Health, 12, 317-328.

Schnitzer, R. J., Bunescu, G., and Baden, V. (1971). Interactions of mineral fiber surfaces with cells in vitro. Annals of the New York Academy of Sciences, 172, 759-771.

- and Pundsack, F. L. (1970). Asbestos hemolysis. Environmental Research, 3, 1-13.

Schulz, R. Z. and Williams, C. R. (1942). Commercial talc: Animal and mineralogical studies. Journal of Industrial Hygiene and Toxicology, 24, 75-79.

Selikoff, I. J. (1970). Partnership for prevention-the insulation industry hygiene research program. Industrial Medicine and Surgery, 39, 162-166.

- - (1973). Widening perspectives of occupational lung diseases. Preventive Medicine, 2, 412-437.

Smith, M. M. (1971). The clinical, radiological and physiological assessment of asbestos and talc workers. Medical Journal of Australia, 2, 1146-1147.

Smith, W. E. (1973). Asbestos, talc and nitrites in relation to gastric cancer. American Industrial Hygiene Association Journal, 34, 227-228.

_, Miller, L., Elsasser, R. E., and Hubert, D. D. (1965). Tests for carcinogenicity of asbestos. Annals of the New York Academy of Sciences, 132, 456-488.

Stalder, K. and Stoeber, W. (1965). Haemolytic activity of suspensions of different silica modifications and inert dusts. Nature, 207, 874-875.

Stanton, M. F. (1974). Editorial. Fiber carcinogenesis:
Is asbestos the only hazard? Journal of the National Cancer Institute, 52, 633-634.

- and Wrench, C. (1972). Mechanisms of mesothelioma induction with asbestos and fibrous glass. Journal of the National Cancer Institute, 48, 797-821.

Thorel, C. (1896). Talc lung. A contribution to the pathological anatomy of pneumoconiosis. Beiträge zur Pathologischen Anatomie und zur Allgemeinen Pathologie, 20, 85-101.

Tortorolo, G. and Romano, C. (1966). Acute pneumopathy due to the inhalation of talc. Minerva Nipiologica, 16, 15-19.

UICC Committee (1970). UICC/Cincinnati classification of the radiographic appearances of pneumoconiosisa cooperative study. Chest, 58, 57-67.

US Food and Drug Administration (1974). Report. Mutagenic Evaluation of Compound FD A 71-43 (1974) Talc. US Department of Commerce. National Technical Information Service No. PB-245, p. 458.

Wagner, J. C., Berry, G., Cooke, T. J., Hill, R. J., and Skidmore, J. W. (1975). Animal experiments with talc. In Proceedings of the 4th International Symposium on Inhaled Particles and Vapours, Edinburgh, September. (To be published.)

- _ - and Timbrell, V. (1973). Mesotheliomata in rats after inoculation with asbestos and other materials. British Journal of Cancer, 28, 173-185.

_- Sleggs, C. A., and Marchand, P. (1960). Diffuse pleural mesothelioma and asbestos exposure in the north western cape province. British Journal of Industrial Medicine, 17, 260-271.

Wegman, D. H., Peters, J. M., Fine, L. J., and Theriault, G. P. (1974). Longitudinal study of talc workers in Vermont. In Proceedings of an American Conference on Industrial Hygiene, Miami Beach, 16 May. (To be published.)

Wehner, A. P., Zwicker, G. M., Cannon, W. C., and Watson, C. R. (1975). Inhalation of baby talc powder by hamsters. In Abstracts from the 18th International Congress on Occupational Health, Brighton, England, September, p. 396.

Weiss, B. and Boettner, E. A. (1967). Commercial talc and talcosis. Archives of Environmental Health, 14, 304-308.

Wright, G. W. (1969). Asbestos and health in 1969. American Review of Respiratory Diseases, 100, 467-479.

Zientara, M. and Moore, S. (1970). Fatal talc embolism in a drug addict. Human Pathology, 1, 324-327.

Received for publication 5 May 1975

Accepted for publication 7 August 1975 